\title{
MEMBANGUN KARAKTER KEMANDIRIAN WIRAUSAHA SANTRI MELALUI SISTEM PENDIDIKAN PONDOK PESANTREN
}

\author{
Riza Zahriyal Falah \\ Institut Agama IsIma Negeri Kudus \\ rizazahriya@stainkudus.ac.id
}

\begin{abstract}
ABSTRAK
Pondok pesantren Al-Mawaddah merupakan salah satu pondok pesantren di kabupaten Kudus yang salah satu tujuan utamanya adalah membentuk karakter santri yang mandiri dalam berwirausaha. Tujuan penulisan artikel ini adalah untuk mengetahui sistem pendidikan pondok pesantren AlMawaddah Kudus dalam membangun membangun karakter kemandirian wirausaha santri yang melingkupi tujuan, kegiatan pembelajaran, dan kegiatan santri. Penelitian yang digunakan adalah penelitian lapangan dengan menggunakan metode penelitian deskriptif kualitatif. Data didapatkan dari proses observasi, wawancara langsung, dan dokumentasi. Dari penelitian yang dilakukan, didapatkan hasil yang pertama, pondok pesantren Al-Mawaddah mempunyai tujuan membentuk santri berkarakter mandiri untuk berwirausaha yang melingkupi mempunyai keberanian mental dalam berwirausaha, mampu mengatur waktu antara menjalankan kegiatan usaha dan kegiatan belajar, dan mampu mengatur keuangan tanpa bergantung kepada orang lain. kedua kegiatan pembelajaran santri dalam masalah ilmu agama hampir sama dengan pesantren pada umumnya yang menggunakan metode sorogan dan bandongan. Dalam pembelajaran wirausaha, selain mendapatkan pembinaan dan pelatihan secara langsung, santri juga mendapatkan motivasi dari pengasuh baik secara langsung (bertemu) mapun tidak langsung (lewat media sosial whastapp). Ketiga kegiatan santri dilingkungan pondok pesantren selain memperdalam ilmu agama dengan mengikuti kajian kitab, khitobah dan kuliah tujuh menit (kultum), dan ceramah kepada masyarakat, juga diisi dengan mengelola usaha-usaha mandiri milik pondok pesantren.
\end{abstract}

Kata Kunci: Karakter, Wirausaha, Sistem Pendidikan, Pondok Pesantren

\footnotetext{
ABSTRACT

Al-Mawaddah Islamic Boarding School is one of the Islamic boarding schools in Kudus district, one of its main goals is to shape the character of students who are independent in entrepreneurship. The purpose of writing this article is to find out the education system of Al-Mawaddah Kudus Islamic boarding school in building the character of the independence of the santri entrepreneurs that encompass goals, learning activities, and activities of
} 
santri. The research used is field research using qualitative descriptive research methods. Data obtained from the process of observation, direct interviews, and documentation. From the research carried out, the first result was that the Al-Mawaddah Islamic boarding school had the goal of forming independent students for entrepreneurship which encompassed having a mental courage in entrepreneurship, being able to manage the time between conducting business activities and learning activities, and being able to manage finance without relying on people other. the two santri learning activities in matters of religious knowledge are almost the same as pesantren in general which use sorogan and bandongan methods. In entrepreneurial learning, in addition to getting direct coaching and training, students also get motivation from caregivers both directly (meeting) and indirectly (via social media whastapp). The three activities of the santri in the Islamic boarding school environment in addition to deepening the knowledge of religion by following the study of the book, khitobah and seven-minute lectures (cult), and lectures to the community, are also filled with managing independent businesses belonging to Islamic boarding schools.

Keywords: Character, Entrepreneurship, Education System, Islamic Boarding School 


\section{PENDAHULUAN}

Dalam pasal 3 undang-undang no 20 tahun 2003 tentang pendidikan nasional, lembaga pendidikan yang berada dalam wilayah Negara Kesatuan Republik Indonesia mempunyai tugas untuk mengembangkan dan membentuk kemampuan dan membentuk watak serta peradaban bangsa yang bermartabat dalam rangka mencerdaskan kehidupan bangsa, bertujuan untuk berkembangnya potensi peserta didik agar menjadi manusia yang beriman dan bertakwa kepada Tuhan Yang Maha Esa, berakhlak mulia, sehat, berilmu, cakap, kreatif, mandiri, dan menjadi warga negara yang demokratis serta bertanggung jawab. Melihat tugas pendidikan nasional tersebut, karakter merupakan salah satu bidang garapan yang tidak bisa dilepaskan dalam proses pendidikan. Salah satu karakter yang dibangun dan dikembangkan pendidikan di Indonesia, sesuai amanat undang-undang tersebut adalah karakter kemandirian. Pendidikan nasional tidak hanya bertujuan mengembangkan potensi peserta didik menjadi manusia yang bertakwa dan beriman, berakhlak mulia, sehat, mempunyai kemampuan kognitif yang baik, cakap, kreatif, mempunyai jiwa demokratis dan bertanggung jawab, tapi juga bertujuan membentuk karakter peserta didik yang mandiri.

Pendidikan karakter bisa dikatakan penting karena sebagaimana diungkapkan Thomas Lickona, ada sepuluh tanda-tanda zaman yang harus diwaspadai apabila tidak ingin tatanan masyarakat hancur. Tanda-tanda itu adalah: (1). violence and vandalism (meningkatnya kekerasan dan sikap merusak dikalangan remaja), (2). stealing (membudayakan ketidak jujuran), (3). cheating (membudayakan penipuan), (4). disrespect for authority (semakin rendahnya rasa hormat pada orang tua dan guru), (5). peer cruetly (penggaruh teman sebaaya dalam tindak kekerasan), (6). bigotry (menurunnya etos kerja), (7). bad language (Penggunaan bahasa dan katakata yang memburuk), (8). sexual procesity and abuse (Meningkatnya perilaku merusak diri, seperti pemakaian narkoba, alkohol, dan seks bebas), (9). increaing self centeredness and declining civic responsibility (meningkatnya individualitas serta rendahnya rasa tanggung jawab bersama), (10). self distructive behavior (tindakan yang merusak dirinya) (Thomas Lickona, 1992: 13-19).

Bertolak dari kenyataan demikian, sudah seharusnya seluruh komponen bangsa memberikan perhatian lebih kepada penyelenggaraan pendidikan yang tidak hanya menekankan pada aspek kognitif saja, tapi juga mengutamakan aspek pembentukan watak dan karakter bangsa dengan landasan etika dan ajaran moral 
yang kokoh. Lembaga pendidikan sebagai salah satu dari tiga pilar pendidikan diluar keluarga dan masyarakat, menempati posisi yang penting dalam mengembangkan karakter peserta didik. Karena tidak bisa dipungkiri, di era globalisasi seperti saat ini, bangsa Indonesia dituntut untuk mampu bersaing secara global, kalau tidak ingin menjadi bangsa yang tertinggal. Sehingga pendidikan tidak hanya terpaku pada pengembangan kognitif peserta didik, tapi juga sebagai sebagai sarana untuk membangkitkan karakter peserta didik yang dapat mengakselerasi pembangunan sekaligus memobilisasi potensi domestik untuk meningkatkan daya saing bangsa (Muslich, 2011). Lembaga pendidikan menjadi salah satu alternatif cara untuk mencapai tujuan tersebut. Pendidikan karakter bukan hanya mengutamakan pengembangan pengetahuan peserta didik, namun juga menekankan pada pembinaan watak atau karakter peserta didik. Melalui pendidikan karakter, dunia pendidikan diharapkan akan menjadi motor penggerak dalam membangun karakter peserta didik dan anggota masyarakat pada umumnya, sehingga memiliki kesadaran kehidupan berbangsa dan bernegara yang kuat, berakhlak, berprinsip dan bermartabat dengan mempertimbangkan norma-norma agama dan budaya masyarakat.

Pesantren sebagai salah satu model lembaga pendidikan, sudah sejak awal menaruh perhatian utama pada penanaman karakter peserta didik. Sebagai salah satu sub sistem pendidikan nasional, pesantren mempunyai karakteristik dan keunggulan yang berbeda dengan lembaga pendidikan yang lain. selain sebagai sub sistem pendidikan nasional, pesantren merupakan lembaga pendidikan yang paling tua yang masih bertahan hingga saat ini. Walaupun sudah bermetamorfosis kedalam beberapa bentuk, namun ciri khas pondok pesantren berupa asrama, santri, kyai/guru utama masih terjaga hingga sekarang. Interaksi guru dan murid di pesantren yang bisa dibilang selama 24 jam, lebih efektif dalam menanamkan nilai-nilai pendidikan karakter, dibandingkan model lembaga pendidikan yang lain. Selain faktor durasi interaksi yang lebih lama dibandingkan lembaga pendidikan lain, kedekatan emosional antara peserta didik/santri dengan kyai dan guru dalam pondok pesantren terjalin lebih intens. Penghormatan santri kepada kyai biasanya lebih total bila dibandingkan penghormatan peserta didik dilembaga pendidikan lain. hal ini terjadi antara lain karena santri dibiasakan untuk bersikap tawadlu/rendah diri dan bersikap sopan baik ketika berada didepan kyai dan guru maupun ketika tidak berhadapan langsung. 
Sebagaimana umunya pondok pesantren, pondok pesantren Enterpreneur AlMawaddah dipimpin oleh seorang kyai, dibantu dengan ibu nyai (istri kyai) dan juga santri-santri yang senior (kemampuannya). Pondok pesantren Enterpereneur AlMawaddah terletak di desa Honggosoco kecamatan Jekulo kabupaten Kudus Jawa Tengah. Seperti tersebut dalam namanya, pondok pesantren Enterpreneur AlMawaddah tidak hanya mengajarkan pendalaman ilmu agama kepada para santri, namun juga mengembangkan berbagai karakter, terutama karakter kemandirian dlam berwirausaha yang merupakan bagian dari arti enterpreneur. Santri pondok pesantren Enterpreneur Al-Mawaddah selain sebagaimana pondok pesantren pada umumnya yaitu mengaji kitab kuning juga dididik untuk hidup mandiri dengan praktik langsung berbagai usaha yang didirikan oleh pondok pesantren. Melihat keunikan fenomena tersebut, penulis tertarik untuk meneliti sistem pendidikan pondok pesantren Enterpreneur Al-Mawaddah dalam membangun karakter kemandirian wirausaha santri.

\section{METODE PENELITIAN}

Pendekatan yang digunakan di dalam penelitian inia adalah kualitatif dengan analitis deskriptif. Data-data yang disajikan yaitu dengan penggambaran tentang obyek penelitian dengan kata sehingga menjadi mudah dipahami. Penelitian ini dilakukan di Pondok Pesantren Enterpreneur Al-Mawaddah di RT 6 RW 1 desa Honggosoco kecamatan Jekulo kabupaten Kudus, kurang lebih sejauh tujuh kilometer dari pusat kota Kudus.

Teknik pengumpulan data dilakukan dengan interview, observasi, dan dokumentasi. Teknik wawancara dilakukan dengan melakukan wawancara kepada pengasuh Pondok Pesantren Enterpreneur Al-Mawaddah, para ustadz pengampu, para santri, serta masyarakat di sekitar Pondok Pesantren Enterpreneur AlMawaddah dan para pemangku kepentingan, termasuk juga para orang tua dan wali.

Wawancara ini dilakukan secara terstruktur, teknik observasi, dengan melihat secara langsung proses pembelajaran yang dilakukan oleh para guru/ustadz, dan dilakukan juga terhadap kondisi suasana pembelajaran ketika dilangsungkan.Teknik dokumentasi, digunakan untuk mengumpulkan dokumentasi-dokumentasi tentang kurikulum pembelajaran, dokumen-dokumen tentang instrumen yang dipakai untuk mengukur derajat pencapaian belajar siswa yang terdapat dalam dokumen evaluasi dan dokumen hasil belajar para santri. 
Teknik Analisis data, menggunakan pola analisis Milles dan Huberman, yaitu dengan melakukan tiga kegiatan yang berjalan berlangsung secara terus menerus sampai penelitian selesai yaitu reduksi data, penyajian data dan penarikan kesimpulan atau verifikasi.

\section{PEMBAHASAN}

\section{Urgensi Pendidikan Karakter}

Karakter berbeda dengan kepribadian. Kepribadian merupakan ciri, karakteristik, atau sifat khas diri seseorang yang bersumber dari bentukan-bentukan yang diterima dari lingkungan, misalnya keluarga pada masa kecil dan bawaan sejak lahir (Koesoema, 2010: 80). berbeda dengan kepribadian, karakter sebagaimana dikemukakan oleh Thomas Lickona adalah "A reliable inner disposition to respond to situation in a morally good way". Jadi karakter lebih mengarah kepada kondisi bathin/jiwa seseorang dalam merespon situasi dengan jalan moral yang baik. Selanjutnya Thomas Lickona menambahkan, "Character so conceived has three interelated parts: moral knowing, moral feeling, and moral behaviour" (Thomas Lickona, 1992: 51). Bahwa karakter mulia meliputi pengetahuan tentang kebaikan (moral knowing) kemudian menimbulkan komitmen atau niat terhadap kebaikan (Moral feeling) dan akhirnya benar-benar melakukan kebaikan (Moral behaviour). Dengan kata lain, karakter mengacu kepada serangkaian pengetahuan (Cognitivies), sikap (Attitudes), dan motivasi (Motivations), serta perilaku (Behaviour), dan keterampilan (Skills). Sehingga dalam pengertian tersebut dapat disimpukan bahwa karakter manusia dapat dirubah dan dikembangkan.

Terkait dengan karakter seseorang bisa berubah dan dikembangkan, Erich Fromm berpendapat bahwa hakikat karakter harus dicari dalam corak hubungan seseorang dengan lingkungannya, benda maupun manusia. Karakter merupakan pola seseorang berhubungan dengan lingkungannya. Atas dasar ini karakter dirumuskan sebagai "the relative permanent form in which human energy is canalized in the process of assimilation and socialization" (Form, 1984: 59). Rumusan tersebut menunjukkan bahwa tolak ukur baik buruknya karakter harus dicari pada proses asimilasi dan sosialisasi, apakah produktif atau tidak. Tipe karakter yang tidak produktif dalam asimilasi di antaranya orientasi reseptif, eksploitatif, penimbun dan orientasi pemasaran, sedangkan dalam sosialisasi berupa karakter mosachism, sadism, dan indifferent. Dikatakan produktif apabila seseorang mampu memanfaatkan 
potensi-potensi dan daya-daya psikisnya (kesadaran diri, imajinasi, dan cinta kasih) secara bebas tanpa tergantung pada orang lain dalam melakspeserta didikan proses asimilasi dan sosialisasi. Orientasi produktif ditandai dengan perealisasian, peningkatan, serta pemanfaatan daya-daya dan potensi-potensi pribadi yang terbawa dan terpadu pada eksistensinya sebagai manusia, yakni akal budi (reason), daya khayal (imajinasi), kesadaran diri (self-awarenessi), cinta kasih (love) dan sebagainya (Falah, 2013: 28).

Pendidikan karakter sebagaimana berkaitan dengan penjelasan karakter diatas, merupakan usaha yang tidak terbatas pada transfer of knowledge and vaue, tapi juga mendidik peserta didik agar dapat mengambil keputusan yang bijak dan mampu mempraktikannya dalam kehidupan sehari-hari. Hasil dari karakter tersebut adalah peserta didik dapat memberikan kontribusi yang positif bagi dirinya dan lingkungannya. Sehingga dapat dipahami bahwa pendidikaan karakter merupakan upaya penanaman kecerdasan dalam berpikir, penghayatan dalam bentuk sikap, dan pengamalan dalam bentuk perilaku yang sesuai dengan nilai-nilai luhur yang menjadi jati diri peserta didik, diwujudkan dalam interaksi dengan Tuhan, diri sendiri, antar sesama dan lingkungannya. Nilai-nilai luhur tersebut antara lain: kejujuran, kemandirian, kesopanan, kemuliaan sosial, kecerdasan berpikir, termasuk kepenasaran intelektual, dan berpikir logis.

Oleh karena itu dalam pendidikan karakter penting adanya penanaman karakter dengan proses seperti peneladanan, pembiasaan atau pembudayaan dalam lingkungan peserta didik dilembaga pendidikan, keluarga dan masyarakat maupun lingkungan media massa. Diharapkan dalam proses tersebut, lembaga pendidikan mampu mengembangkan nilai-nilai karakter pada peserta didik, sehingga mereka mempunyai nilai dan karakter sebagai bagian dari dirinya, menerapkan nilai-nilai tersebut dalam kehidupan dirinya, sebagai anggota masyarakat dan warga negara yang religius, nasionalis, produktif dan kreatif (Judiani, 2010). Dalam halnya karakter kemandirian, santri pondok pesantren merupakan peserta didik yang lepas dari pengawasan orang tua, dan selama 24 jam berada dalam pengawasan kyai atau guru yang ada di pondok pesantren. Sehingga perana kyai dan guru tidak hanya mendidik, tapi juga menjadi oran tua pengganti bagi para santri. Intensitas yang sedemikian lama, membuat kyai dan guru di pondok pesantren menjadi figur yang harus ditiru dan didengar. Lepasnya santri dari pengawasan orang tua, membuatnya akan terbiasa melakukan berbagai sendiri. Tentunya dengan arahan guru yang ada di pondok 
pesantren, santri akan berimprovisasi untuk membuat dirinya nyaman dan betah berada di pondok pesantren. Improvisasi itu yang kemudian memunculkan jiwa mandiri dalam diri santri. Karena terbiasa melakukan apapun sendirian.

Karakter kemandirian inilah yang menjadi salah satu titik tekan karakter yang dikembangkan di pondok pesantren. Sehingga banyak pondok pesantren yang motto yang dikembangkan adalah jiwa keikhlasan, kesederhanaan, kemandirian, persaudaraan, dan kebebasan (Makmun, 2014). Dalam konteks motto atau peganga hidup ini, penyelenggara pendidikan harus merumuskan karakter dasar yang dikembangkan dan diinternalisasikan kepada peserta didik. Ratna Megawangi melalui Indonesia Heritage Foundation (IHF) merumuskan sembilan karakter dasar yang dijadikan tujuan pendidikan karakter, yaitu (1) cinta kepada Allah dan semesta beserta isinya, (2) tanggung jawab, disiplin dan mandiri, (3) jujur, (4) hormat dan santun, (5) peduli, kerja sama dan kasih sayang, (6) percaya diri, kreatif, pantang menyerah, dan kerja keras, (7) keadilan dan kepemimpinan, (8) baik dan rendah hati, (9) toleransi, cinta damai, dan persatuan (Megawangi, 2007). Sedangkan Living Values: An Education Program (LVEP) yang didukung oleh UNESCO, Planet Society, dan Brahmana Kumaris, dengan bimbingan dari Education Chuster dari UNICEF merumukan karater yang harus dikembangkan dan diiternalisasikan ada 12, yaitu 1) kedamaian, 2) penghargaan, 3) cinta, 4) tanggung jawab, 5) kebahagiaan, 6) kerja sama, 7) kejujuran, 8) kerendahan hati, 9) toleransi, 10) persatuan, 11) kesederhanaan, dan 12) kebebasan (Diane Tilman, 2004: 20). Sedangkan Lickona menyebutkan karakter dasar yang harus dikembangkan melalui pendidikan karakter ada sepuluh karakter yang disebut dengan "Ten Essential Fietues". Sepuluh kebajikan terpenting tersebut adalah: wisdom, justice, fortitude, self-controle, love, positive attitude, hard work, integrity, gratitude, dan humanity (Lickona, 2003: 3).

Dalam konteks pendidikan Islam, karakter atau akhlak yang ditanamkan pada peserta didik harus berlandaskan pada dua dimensi kehidupan manusia, yaitu dimensi ke-Tuhanan dan dimensi kemanusiaan (Madjid, 2000: 96). Kedua dimensi ini dikembangkan untuk menumbuhkan karakter atau akhlak peserta didik agar memiliki rasa ketakwaan kepada Allah SWT dan rasa kemanusiaan kepada sesama manusia. Dimensi ke-Tuhanan yang biasa disebut rabbaniyyah yang akan melahirkan nilai-nilai keagamaan yang mendasar bagi manusia yang amat penting ditanamkan pada peserta didik-peserta didik. Diantara nilai-nilai kegunaan yang sangat mendasar itu adalah iman, Islami, ikhsan, taqwa, ikhlas, tawakkal, syukur dan sabar (Madjid, 2000: 
88). Sedangkan dimensi kemanusiaan yang melahirkan nilai-nilai luhur (al-akhlak alkarimah) yang diwujudkan secara nyata dalam perilaku sehari-hari antara lain adalah silaturahmi, persaudaraan, egaliter, baik sangka, keadilan, rendah hati, tepat janji, lapang dada, dapat dipercaya, perwira, hemat, dan dermawan (Madjid, 2000: 101).

Berdasarkan uraian diatas, karakter dasar dapat dikelompokkan menjadi 3 macam, yaitu: (1) karakter yang berkaitan dengan nilai-nilai ketuhanan (ilahiyyah) seperti iman, Islam, ikhsan, taqwa, ikhlas, tawakkal, syukur, dan sabar; (2) karakter yang berkaitan dengan nilai-nilai kemanusiaan yang bersifat universal, seperti kedamaian, toleransi, persatuan, justice, humanity, kasih sayang, silaturahmi, persaudaraan, persamaan, keadilan, dan kepemimpinan; (3) karakter yang berkaitan dengan nilai-nilai kemanusiaan sebagai makhuk individu, seperti hard work, integrity, positive attitude, self-control, kejujuran, kesederhanaan, kreatif, tanggung jwab, disiplin, rendah hati, menepati janji, lapang dada, dapat dipercaya, perwira, hemat, dan mandiri. Pentingnya internalisasi karakter kepada peserta didik adalah agar peserta didik mengetahui kebaikan (Knowing the good), mencintai kebaikan (Loving the good), dan melakukan kebaikan (doing the good).

\section{Profil Pondok Pesantren Enterpreneur Al-Mawaddah}

Pondok pesantren Enterpreneur Al-Mawaddah merupakan salah satu pondok pesantren yang berada di kabupaten Kudus, tepatnya di RT 6 RW 1 desa Honggosoco kecamatan Jekulo kabupaten Kudus, kurang lebih sejauh tujuh kilometer dari pusat kota Kudus. Pondok pesantren Enterpreneur Al-Mawaddah didirikan dan diasuh oleh $\mathrm{KH}$. Sofiyan Hadi, Lc. Inspirasi awal pendirian pesantren ini adalah berasal dari pengalaman pengasuh baik ketika belajar di pondok pesantren maupun ketika menyelesaikan studi di Universitas Al-Azhar Mesir (Hadi, n.d.). KH. Sofyan Hadi, Lc mendapatkan beasiswa dari Universitas Al-Azhar. Setelah diamati, didapatkan kesimpulan bahwa selain berfokus pada pendidikan, Universitas Al-Azhar juga berfokus pada salah satunya adalah lembaga-lembaga usaha. Laba dari lembaga usaha itu kemudian digunakan oleh Al-Azhar salah satunya untuk memberikan beasiswa kepada para mahasiswa, baik yang berasal dari Mesir maupun dari luar Mesir, termasuk salah satunya adalah KH. Sofiyan Hadi. Dari sini, KH. Sofiyan Hadi mempunyai keinginan yang sama untuk mendirikan lembaga pendidikan tanpa menarik biaya dari peserta didik. Selain sebagai bentuk kepedulian sosial kepada para santri, niat tersebut juga memberikan edukasi kepada lembaga pendidikan lain agar bisa mandiri dalam memenuhi kebutuhan operasional lembaganya. Selain itu, $\mathrm{KH}$. 
Sofiyan Hadi juga melihat bahwa tidak seharusnya lembaga pendidikan menarik pembiayaan yang memberatkan peserta didik. Karena sudah seharusnya sebagai sesama warga negara saling bahu-membahu mengentaskan kebodohan dan kemiskinan.

Dalam mengelola pondok pesantren Enterpreneur Al-Mawaddah, KH. Sofiyan dibantu istrinya dan juga santri-santri yang dianggap mampu menjadi pengurus pondok pesantren. Selain itu juga ada dewan guru yang ikut mengajar santri. Pembelajaran hampir sama dengan pondok-pondok lain, yaitu menggunakan sistem bandongan untuk kajian kitab kuning, dan sorogan untuk pengajian Al-Qur'an. Selain menggunakan dua metode tersebut, santri juga diberi waktu untuk praktik secara langsung, seperti mengisi kultum (kuliah tujuh menit) diforum pengajian ahad sore yang dihadiri masyarakat sekitar pondok. Selain itu juga ada kegiatan khitobah atau pidato setiap malam Jum'at. Setiap santri mendapatkan jadwal untuk mengisi kegiatan ini. Tema yang umum biasanya adalah sejarah Nabi Muhammad SAW dengan selipan motivasi untuk mandiri berwirausaha (Syaf, n.d.).

Saat ini, pondok pesantren Enterpreneur Al-Mawaddah memiliki kurang lebih 35 santri putra dan putri. Hal ini karena setiap santri dituntut untuk bisa menyesuaikan diri dengan kegiatan pondok. Selain itu, santri juga dilarang menerima kiriman uang dari orang tua atau walinya. Walapun secara teknis masalah kiriman orang tua ini tidak bisa diawasi, namun pengasuh percaya bahwa santri menjalankan amanat tersebut. Dengan jumlah santri tersebut, KH. Sofiyan Hadi dibantu istri dan juga pengurus, mengorganisasi kegiatan santri dan kegiatan usaha pondok pesantren (Syaf, n.d.).

Berbagai usaha pondok pesantren Enterpreneur Al-Mawaddah sudah secara mandiri dikelola oleh santri, dengan pengawasan pengasuh. Usaha-usaha itu antara lain mini pom bensin, mini market, jembatan timbang, stand cokelat, stand jajanan olahan daging dan stand-stand lain, eduwisata, yaitu wisata alam sambil belajar, training/motivasi/pesantren kilat, biro haji dan umroh, dan lain-lain. Pondok pesantren Enterpreneur Al-Mawaddah juga memberikan perhatian khusus kepada warga masyarakat. Tidak hanya dengan mengadakan pengajian rutin, tapi juga dalam bentuk memajukan kesejahteraan masyarakat sekitar pondok(Hadi, n.d.). Usaha mensejahterakan ini diwujudkan dengan cara mengedukasi para petani dalam mengelola hasil panen seperti tebu, singkong, dan tanaman hydporonik. Edukasi yang diberikan adalah cara bercocok tanam yang baik, pengolahan panen yang baik, juga penjualan hasil panen yang menguntungkan. Selain pertanian, pondok pesantren juga 
menerima produk olahan jadi dari masyarakat sekitar pondok untuk kemudian dijual di mini market pondok pesantren. Sasaran pembeli yang paling utama adalah pengunjung pondok pesantren yang mengikuti kegiatan eduwisata, atau training motivasi atau sekedar outbond. Setelah kegiatan selesai, pengunjung diarahkan untuk mengunjungi usaha-usaha pondok pesantren.

Dengan manajemen yang baik, pondok pesantren Enterpreneur Al-Mawaddah mampu membiayai biaya sehari-hari semua santri (makan, sarana prasarana, dan guru), dan juga memberikan uang saku/gaji/pesangon kepada para santri setiap bulan. Pemberian gaji/pesangon bulanan ini diatur oleh ibu pengasuh dibantu pengurus dengan memperhatikan kinerja santri dalam satu bulan. Berbagai kegiatan usaha yang didirikan dan dikelola pondok pesantren Enterpereneur Al-Mawaddah, pada saat ini juga iku berkontribusi memajukan berbagai usaha masyarakat sekitar pondok pesantren. Utamanya usaha yang berbentuk produk jadi dan hasil pertanian seperti tebu dan singkong (Hadi, n.d.). Selain pengabdian kepada masyarakat berupa kegiatan keagamaan (pengajian), pondok pesantren Enterpreneur juga memotivasi dan mengedukasi serta menampung kegiatan usaha masyarakat. pemikiran ini berangkat dari keinginan $\mathrm{KH}$. Sofiyan Hadi untuk mengembangkan pengetahuan dan kegiatan usaha masyarakat sekitar pesantren, sehingga perekonomian masyaraakat bisa berkembang serta mandiri (Hadi, 2016).

\section{Metode Pengembangan Karakter Kemandirian Kewirausahaan dalam Pendidikan}

Berbagai upaya yang dilakukan untuk merealisasikan tujuan pendidikan hanya dapat diselesaikan dan di-cover oleh langkah dari sebuah metode yang digunakan. Hal tersebut merupakan sebuah langkah kongkritisasi atas fase perencanaan menuju fase memperoleh hasil tujuan. Adapun tujuan umum metode pendidikan karakter dalam pendidikan Islam, yang merujuk pada pendapat Umar Muhammad al-Thoumy al-Syaibani yang intinya adalah, pertama membantu peserta didik dalam mengembangkan pengetahuan sikap dan ketrampilan, sehingga timbul kesadaran peserta didik untuk selalu melakukan kebaikan dalam hidupnya. Kedua, meningkatkan hubungan antara pendidik dan peserta didik, serta saling hormat menghormati, dan juga menjadikan guru sebagai teladan untuk membentuk karakternya. Ketiga, mempermudah proses pendidikan karakter, penciptaan suasana yang kondusif untuk penanaman nilai-nilai kebaikan dalam mencapai tujuan pendidikan karakter yang diinginkan secara optimal (Al-Syaibani, 1979: 585). Untuk 
mencapai tujuan pendidikan karakter yang diharapkan, dibutuhkan metode yang tepat agar pencapaiannya semakin terarah dan efektif. Untuk membangun karakter yang baik, metode yang digunakan tidak hanya bagi peningkatan aspek kognitif, akan tetapi harus seluruh dimensi spiritual, emosi, kreativitas, sosial dan motorik juga harus dikembangkan secara terfokus dan terstruktur. Berbagai metode pendidikan karakter dirumuskan oleh para ahli, salah satunya sebagaimana dirumuskan oleh Furqon Hidayatullah yang membagi metode pendidikan karakter menjadi lima macam. Yaitu: 1) Metode keteladanan, 2) Metode penanaman disiplin, 3) Metode pembiasaan, 4) Metode menciptakan suasana yang kondusif, 5) Metode integrasi dan internalisasi (Hidayatullah, 2010: 40).

Keteladanan dalam pendidikan adalah metode influentif yang paling meyakinkan keberhasilannya dalam mempersiapkan dan membentuk peserta didik di dalam moral, spiritual dan sosial. Hal ini adalah karena pendidik adalah contoh terbaik dalam pandangan peserta didik, yang akan ditiru dalam tindak tanduknya dan tata santunnya, disadari atau tidak, bahkan tercetak dalam jiwa dan perasaan peserta didik suatu gambaran pendidik tersebut, baik ucapan atau perbuatan, material maupun spiritual, diketahui maupun tidak diketahui. Dalam pendidikan karakter, permodelan atau pemberian teladan merupakan metode yang tepat digunakan. Hal ini karena mengingat bahwa karakter merupakan perilaku (behaviour), bukan pengetahuan sehingga sehingga dalam internalisasinya pada peserta didik lebih tepat dengan diteladankan, bukan diajarkan. Al-Ghazali menganjurkan kepada setiap pendidik agar selalu menjadi teladan dan pusat perhatian bagi peserta didik didiknya. Pendidik harus mempunyai kharisma yang tinggi. Dan hal ini merupakan faktor utama bagi pendidik untuk membawa peserta didik kearah yang menjadi tujuan pendidikan (Rusn, 1998: 70).

Pengasuh dalam lembaga pendidikan pondok pesantren merupakan figur sentral dalam pendidikan karakter. Ditambah pengasuh selama kurang lebih 24 jam berinteraksi dengan santri. Sehingga segala perbuatan dan ucapan pengasuh menjadi perhatian peserta didik. Interaksi yang sedemikian intens ditambah dengan kharisma yang dimiliki pengasuh, menjadikan internalisasi pendidikan karakter di pondok pesantren berjalan efektif dan mencapai tujuan. Selain figur pengasuh, juga terdapat figur guru yang memiliki interaksi yang hampir sama dengan pengasuh, sehingga penanaman karakter berjalan sistematis dan komprehensif. Keteladanan yang diberikan pengasuh tidak hanya terbatas pada forum-forum pengajian, tapi juga 
diluar itu. KH. Sofiyan Hadi dalam pembelajaran sehari-hari di pondok pesantren Enterpreneur Al-Mawaddah, selalu menyelipkan pesan-pesan kemandirian berwirausaha kepada peserta didik. Pesan-pesan kemandirian berwirausaha itu diambil dari berbagai sumber, utamanya adalah sirah nabawiyah (sejarah Nabi) dan juga sahabat (Hadi, n.d.). Pesan-pesan ini juga disampaikan lewat aplikasi media sosial Whatsapp. Dengan membuat grup whatsapp khusus untuk santri dan pengasuh, hampir setiap malam, KH. Sofiyan Hadi memberikan ceramah-ceramah berisi motivasi untuk mandiri dalam berwirausaha (Syaf, n.d.). Selain motivasi verbal, $\mathrm{KH}$. Sofiyan Hadi juga memberikan keteladanan berupa sikap dan perilaku. Dalam hal ini, $\mathrm{KH}$. Sofiyan dibantu istri selalu memberikan teladan dengan terjun langsung ke unit-unit usaha pondok pesantren. Selain untuk memotivasi, juga sebagai bentuk pegawasan dan perhatian kepada santri. KH. Sofiyan Hadi juga memberikan contoh tentang cara berwirausaha yang baik dan jujur. Selain itu juga tidak lupa diteladankan sikap ta'awun (saling tolong-menolong). Dibuktikan dengan kegiatan membantu masyarakat sekitar pondok dalam berwirausaha dan bertani.

Metode kedua yang dipakai di pondok pesantren Enterpreneur Al-Mawaddah dalam menginternalisasikan karakter kemandirian wirausaha adalah metode penanaman kedisiplinan. Disiplin pada hakikatnya merupakan ketaatan yang sungguh-sungguh yang didukung oleh kesadaran untuk menunaikan tugas dan kewajiban serta berperilaku sebagaimana mestinya menurut aturan-aturan dan tata perilaku yang berlaku di dalam suatu lingkungan tertentu (Hidayatullah, 2010: 45). Realisasinya harus terlihat atau menjelma dalam perbuatan atau tingkah laku yang nyata, yaitu perbuatan tingkah laku yang sesuai dengan atuan-aturan atau tata kelakuan yang semestinya. Oleh karena itu, pentingnya menegakkan disiplin agar sesuatu yang diinginkan dapat tercapai dengan tepat waktu. Menanamkan prinsip agar peserta didik memiliki pendirian yang kokoh merupakan bagian yang sangat penting dalam menegakkan disiplin. Dengan demikian penegakan disiplin merupakan salah satu metode dalam membangun karakter seseorang. Jika penegakan disiplin dapat dilakukan secara berulang-ulang dan terus menerus, maka lama kelamaan akan menjadi habit atau kebiasaan yang positif.

Penegakan disiplin di pondok pesantren Al-Mawaddah berjalan sistematis. Santri yang menjadi pengurus diberi tugas pengasuh untuk mengawasi dan mengontrol santri lain. pengurus akan melaporkan perkembangan kegiatan santri kepada ibu pengasuh (Muhanifah, n.d.). Ibu pengasuhlah yang kemudian memberikan 
solusi terhadap permasalahan santri. Dalam kegiatan wirausaha juga berjalan demikian adanya. Pengurus santri mengawasi, mengorganisir, dan mengevaluasi yang kemudia memberikan laporannya ke ibu pengasuh. Santri yang bermasalah akan dinasehati dan dimotivasi untuk belajar dari masalahnya dan memperbaiki kesalahannya. Dari berbagai kegiatan pembelajaran maupun wirausaha yang sedemikian rupa, memberikan andil dalam seleksi terhadap santri yang mampu atau tidak mampu mengikuti ritme kegiatan di pondok pesantren. Terlihat dengan adanya santri yang mengundurkan diri dari pondok karena tidak bisa mengikuti ritme kegiatan pondok. Ketidaksanggupan itu terlihat dengan sikap tidak bisa disiplin dalam mengikuti kegiatan pembelajaran maupun kegiatan wirausaha (Syaf, n.d.).

Metode yang ketiga adalah metode pembiasaan. Menurut Dorothy Law Notle dalam Dryden dan Vos, sebagaimana dikutip oleh Furqon Hidayatullah mengatakan bahwa anak belajar dari kehidupan yang melingkupinya. Beberapa dari pernyataan itu adalah:

Jika anak dibesarkan dengan dorongan, ia belajar percaya diri, Jika anak dibesarkan dengan toleransi, ia belajar menahan diri, Jika anak dibesarkan dengan pujian, ia belajar menghargai, Jika anak dibesarkan dengan penerimaan, ia belajar mencintai, Jika anak dibesarkan dengan dukungan, ia belajar menyenangi diri, Jika anak dibesarkan dengan persahabatan, ia belajar menemukan cinta dalam kehidupan,

Jika anak dibesarkan dengan pengakuan, ia belajar mengenali tujuan,

Jika anak dibesarkan dengan celaan, ia belajar memaki,

Jika anak dibesarkan dengan permusuhan, ia belajar berkelahi,

Jika anak dibesarkan dengan olok-olok, ia belajar rendah diri,

Jika anak dibesarkan dengan iri hati, ia belajar kedengkian,

Jika anak dibesarkan dengan ketakutan, ia belajar gelisah (Hidayatullah, 2010: 111).

Ungkapan Dorothy Low Notle tersebut menggambarkan bahwa anak akan tumbuh sebagaimana lingkungan yang mengajarinya dan lingkungan tersebut juga merupakan sesuatu yang menjadi kebiasaan yang dihadapinya setiap hari. Jika seorang anak tumbuh dalam lingkungan yang mengajarinya berbuat baik, maka diharapkan ia akan terbiasa untuk selalu berbuat baik. Sebaliknya jika seorang anak 
tumbuh dalam lingkungan yang mengajarinya berbuat kejahatan, kekerasan, maka ia akan tumbuh menjadi pelaku kekerasan dan kejahatan yang baru.

Sebagaimana umumnya pondok pesantren, pondok pesantren Enterpreneur Al-Mawaddah membiasakan para santri dengan perbuatan-perbuatan yang baik dan berfaidah. Utamanya dalam menumbuhkan karakter mandiri kewirausahaan. Santri dididik dengan terjun langsung mengelola dan mengembangkan kegiatan-kegiatan usaha milik pondok pesantren. Kegiatan ini juga diperkuat dengan pemberian nasehat, pesan-pesan kebaikan dan kejujuran, serta motivasi dari pengasuh secara langsung kepada santri lewat forum pengajian maupun lewat media sosial whatsapp (Hadi, n.d.).

Pembiasaan atau habituation merupakan proses pembentukan sikap dan perilaku yang relatif menetap dan bersifat otomatis melalui proses pembelajaran yang berulang-ulang. Sikap atau perilaku yang menjadi kebiasaan mempunyai ciri seperti perilaku tersebut relatif menetap, umumnya tidak memerlukan fungsi berpikir yang cukup tinggi, misalnya untuk dapat mengucapkan salam cukup fungsi berpikir berupa mengingat atau meniru saja, bukan sebagai hasil dari proses kematangan, tetapi sebagai akibat atau hasil pengalaman atau belajar, dan tampil secara berulang-ulang sebagai respons terhadap stimulus yang sama. Terdapat sedikit perbedaan antara proses keteladanan dan proses pembiasaan. Akan tetapi kedua hal tersebut saling menunjang. Keteladanan merupakan konotasi kata yang positif, sehingga hal-hal yang mengikuti adalah perilaku, sikap, maupun perbuatan yang secara normatif baik dan benar. Dalam keteladanan terdapat unsur mengajak secara tidak langsung, sehingga terkadang kurang efektif tanpa ada ajakan secara langsung yang berupa pembiasaan. Begitu pula dengan pembiasaan yang secara langsung mengarahkan pada suatu perilaku, sikap maupun perbuatan yang diharapkan, kurang dapat berhasil dengan baik tanpa adanya keteladanan. Sehingga selain keteladanan, pembiasaan juga memegang aspek yang penting dalam proses penanaman karakter.

Santri pondok pesantren Enterpreneur Al-Mawaddah dibiasakan dengan kegiatan-kegiatan wirausaha. Didukung dengan metode kedisiplinan, para santri dibiasakan untuk mandiri mengurusi usaha pondok pesantren yang menjadi tanggung jawabnya. Seperti contoh santri yang mendapatkan tugas menjalankan usaha SPBU Mini, maka setiap hari santri tersebut harus mengatur ketersediaan stok bahan bakar, serta membuat laporan perhari dan perbulan (Syaf, n.d.). Dalam hal ini pada awalnya metode yang dipakai adalah kedisiplinan, namun semakin lama adalah pembiasaan 
dibarengi keteladanan. Sehingga pada akhirnya dalam melaksanakan tugasnya, santri tidak lagi merasa terbebani karena sudah memiliki karakter kemandirian.

Metode keempat adalah metode menciptakan suasana kondusif. Dari hasil observasi penulis, didapatkan temuan bahwa KH. Sofiyan Hadi selaku pengasuh telah mengelola lingkungan pondok pesantren sedemikian rupa, sehingga menunjang program-program penanaman karakter kemandirian wirausaha. Antara satu unit usaha dengan unit usaha yang lain, diatur sedemikian rupa. Terlihat dengan adanya minimarket dan lapak-lapak makanan cepat saji didepan pondok pesantren, jembatan timbang dan SPBU Mini disamping barat pondok pesantren, serta eduwisata dan outbond dibelakang pondok pesantren. Tempat pelatihan dan motivasi juga diatur sedemikian rupa memudahkan proses pengawasan dan kontrol serta komunikasi antar santri. Asrama santri juga ditata sedemikian rupa sehingga menyerupai tamantaman yang asri yang membuat santri serta pengunjung betah berada di pondok pesantren. Dengan suasana lingkungan yang kondusif tadi, proses internaliasi karakter kemandirian wirausaha santri berjalan dengan baik. Karena didukung dengan fasilitas dan lingkungan yang memadai. Lingkungan dapat dikatakan merupakan proses pembudayaan peserta didik yang dipengaruhi oleh kondisi yang setiap saat dihadapi dan dialami oleh peserta didik. Demikian halnya, menciptakan suasana yang kondusif di rumah, di sekolah maupun di lingkungan dimana anak tinggal merupakan upaya membangun kultur atau budaya yang memungkinkan untuk membangun karakter, Tentunya bukan hanya budaya akademik yang dibangun tetapi juga budayabudaya yang lainnya, seperti membangun budaya untuk hidup mandiri.

Metode yang terakhir adalah integrasi dan internalisasi. Pendidikan karakter membutuhkan proses internalisasi nilai-nilai ke dalam hati peserta didik agar tumbuh dari dalam. Nilai-nilai karakter seperti kemandirian, menghargai orang, jujur, amanah, disiplin sabar, dan lain-lain dan diinternalisasikan ke dalam seluruh kegiatan peserta didik. Hal ini sejalan dengan definisi dari pendidikan yaitu transfer of knowledge and value. Penanaman karakter ini dilaksanakan terus menerus sehingga tertanam kuat di hati peserta didik. Selain internalisasi, juga harus ada integrasi antara satu metode dengan metode yang lain, juga satu karakter dengan kondisi lingkungan. hal ini berangkat dari kenyataan bahwa fenomena atau fakta yang ada di dalam kehidupan dan di lingkungan selalu terkait dengan fenomena atau aspek yang lain. oleh karena itu, suatu fenomena dapat dipandang sebagai suatu sistem, kesatuan atau keterpaduan. Implikasi dari kondisi tersebut adalah bahwa dalam memandang dan 
mengkaji suatu fenomena harus dikaitkan dengan konteks yang ada. Internalisasi dalam pengembangan karakter kemandirian wirausaha santri pondok pesantren AlMawaddah terdapat dalam satu kesatuan pengelolaan pendidikan di pondok pesantren yang dilakukan oleh $\mathrm{KH}$. Sofiyan Hadi dibantu istri dan pengurus pondok pesantren. internalisasi dilakukan hampir selama 24 jam lewat kegiatan terstruktur maupun non terstruktur. Kegiatan terstruktur seperti lewat forum pengajian dan media sosial. sedangkan kegiatan non struktur seperti kontrol dan evaluasi diluar kegiatan terstruktur. Terkait dengan karakter kemandirian berwirausaha, integrasinya adalah dengan cara menerjunkan langsung santri dalam kegiatan usaha pondok pesantren, membuat aturan santri dilarang menerima/meminta dari/kepada orang tua, dengan cara memenuhi kebutuhan santri selama tingga di pondok pesantren. sehingga santri tidak hanya belajar agama, tapi juga mempunyai kemampuan untuk secara mandiri berwirausaha. Hal ini dibuktikan dengan beberapa alumni pondok pesantren Enterpreneur Al-Mawaddah yang menciptakan lapangan kerja ketika pulang ke daerahnya masing-masing (Syaf, n.d.).

\section{SIMPULAN}

Dari penjelasan deskriptif hasil penelitian, didapatkan kesimpulan bahwa karakter yang dibangun pondok pesantren Enterpreneur Al-Mawaddah adalah menitik beratkan pada karakter kemandirian berwirausaha. Dibuktikan dengan kegiatan santri selain mengaji/belajar juga menjalankan, mengorganisir serta mengevaluasi kegiatan usaha pondok pesantren. pondok pesantren Enterpreneur Al-Mawaddah seperti umumnya pondok pesantren menggunakan metode sorogan dan bandongan dalam pembelajaran. selain itu juga ada praktik keilmuan agama lewat kegiatan khitobah dan kultum (kuliah tujuh menit). Sedangkan dalam proses pengembangan karakter kemandirian berwirausaha, metode yang digunakan adalah metode keteladanan, penanaman disiplin, pembiasaan, menciptakan suasana yang kondusif, serta integrasi dan internalisasi. Dengan metode ini proses pengembangan karakter kemandirian wirausaha santri berjalan dengan baik serta sistematis.

\section{DAFTAR PUSTAKA}

Al-Syaibani, O. M. al-T. (1979). Falsafah Pendidikan Islam. Jakarta: Bulan Bintang. 
Diane Tilman 2004), hlm. 20. (2004). Living Values for Activities Children Ages 8-14: Pendidikan Nilai untuk Anak Usia 8-14. Jakarta: Gramedia Widiasarana Indonesia.

Falah, R. Z. (2013). Pendidikan Karakter: Studi Analisis terhadap Pemikiran dan Implementasi Pendidikan Karakter KH. Ali Maksum. UIN Sunan Kalijaga Yogyakarta.

Form, E. (1984). Man for Himself; Inquiry into Psychology of Ethics. New York: Hol, Rinebart and Wisdom.

Hadi, K. S. (n.d.). Wawancara pada tanggal 29 April 2018. Kudus.

Hadi, K. S. (2016). Profil Pesantren Entrepreneur Al-Mawaddah Kudus. Retrieved June 25, 2018, from mawaddahkudus.blogspot.com/2017/07/profil-pesantrenentrepreneur-al.html

Hidayatullah, M. F. (2010). Pendidikan Karakter: Membangun Peradaban Bangsa. Surakarta: Yuma Pustaka.

Judiani, S. (2010). Implementasi Pendidikan Karakter di Sekolah Dasar Melalui Penguatan Pelaksanaan Kurikulum. Jurnal Pendidikan Dan Kebudayaan, 16(9), 280-289. Retrieved from http://jurnaldikbud.kemdikbud.go.id/index.php/jpnk/article/view/519

Koesoema, D. (2010). Pendidikan Karakter: Strategi Mendidik Anak di Zaman Global. Jakarta: Grasindo.

Lickona, T. (2003). the Fourth and Fifth R.S (10th ed.). Cortland: School of Education. Madjid, N. (2000). Masyarakat Religius; Membumikan Nilai-Nilai Islam dalam Kehidupan Masyarakat. Jakarta: Paramadina.

Makmun, H. A. R. (2014). Pembentukan Karakter Berbasis Pendidikan Pesantren: Cendikia, 12(2), 212-238.

Megawangi, R. (2007). Pendidikan Karakter. Cimanggis: Indonesian Heritage Foundation.

Muhanifah. (n.d.). Wawancara pada tanggal 23 Mei 2018. Kudus.

Muslich, M. (2011). Karakter: Menjawab Tantangan Krisis Multidimensional. Jakarta: Bumi Aksara.

Rusn, A. I. (1998). Pemikiran Al-Ghazali Tentang Pendidikan (1st ed.). Yogyakarta: Pustaka Pelajar.

Syaf, M. L. (n.d.). Wawancara pada tanggal 23 Mei 2018. Kudus. 
Jurnal Tarbawi Vol. 15. No. 2. Juli - Desember 2018 | I27

Thomas Lickona. (1992). Educating for Character How Our School Can Teach Respect and Responsibility. New York: Bantam Book. 
I28 | Jurnal Tarbawi Vol. I5. No. 2. Juli - Desember 2018 